\title{
Unintended Consequences in Implementing Public Sector Accounting Reforms in Emerging Economies: Evidence from Egypt, Nepal and Sri Lanka
}

Pawan Adhikari, Chamara Kuruppu, Hassan Ouda, Giuseppe Grossi and Dayananda Ambalangodage

\begin{abstract}
Drawing on diffusion theory, this study investigates the implementation of public sector accounting reforms in three emerging economies - Egypt, Nepal and Sri Lanka. Data for the paper are derived through document analysis and semi structured interviews with public administrators, government accountants and members of professional accountancy bodies. The paper brings out the factors, including the bundling process, pro-innovation biases, informal and interpersonal networks, a boundary spanning process, organisational communication, power disparity, and dominance, all of which have either individually or collectively stifled the diffusion trajectory of public sector accounting reforms in Egypt, Nepal and Sri Lanka at the implementation phase. As a result, public sector accounting reforms have resulted in resistance, internal conflicts and unintended consequences, including the fabrication of results, in all three countries without any evidence of yielding better results for public sector governance and accountability.
\end{abstract}

\section{Points for practitioners}

Public sector accounting practitioners should realise the importance of considering the specific contexts of emerging economies, including the power structures, communication channels, informal networks and communication flows prior to the diffusion of reforms. When such contextual elements are deemphasised, reforms would tend to encounter delay and resistance, ongoing reforms in Egypt, Nepal and Sri Lanka serving as examples. Also, instead of delegating power to professional accountants and expert groups, they can be employed as boundary spanners to facilitate communication with government accountants, administrators and other stakeholders about the technical complexities of public sector accounting reforms. This may help establish an efficient communication network and strengthen interpersonal and informal networks enabling reforms to pass through the diffusion trajectory without being stifled at the implementation phase.

Keywords: Accrual accounting; Diffusion theory; Emerging economies; the Cash Basis IPSAS; Public sector. 


\section{Introduction}

This paper aims at investigating the implementation of public sector accounting reforms in emerging economies, drawing evidence from Egypt, Nepal and Sri Lanka. That these reforms have evolved as a dominant development discourse in the structural adjustment programmes and loan conditionality of international organisations to emerging economies is covered in prior work (Van Helden and Uddin, 2016). The existing accounting practices in emerging economies, built on the cash principle, have been long claimed by the World Bank to be inadequate (Rahaman and Lawrence, 2001) in terms of improving governance and stimulating economic growth (Hopper et al., 2017). Accrual accounting has been diffused to these countries, labelled as a 'best accounting practice' and an 'accounting innovation' (Adhikari et al., 2015), on account of its adoption by western countries and propagating several benefits ranging from improving fiscal transparency to sustainability of government activities (IFAC, 2011). Many of such benefits have remained untested and are claimed to be overexaggerated, even in western country contexts (Wall and Connolly, 2016), let alone emerging economies.

Debates on the significance of accrual accounting in the public sector and the challenges experienced in its implementation across western countries have rarely been recognised by international organisations (Hopper et al., 2017). More recently, emerging economies have been offered an alternative incremental route towards accrual accounting, first by complying with the requirements of the Cash Basis International Public Sector Accounting Standard (IPSAS), and then by instigating a transition in the longer term having achieved the required competence and capability (Rajib et al., 2019). However, previous studies demonstrate that not only have such externally sponsored public sector accounting reforms remained ineffective in practice, but, in many cases, the results of the reforms have been rather disappointing. For instance, Brusca et al. (2016) state that the modernisation of public sector accounting in Latin American countries has become more rhetorical than real, although there has been an unabated momentum towards accrual accounting. Russia and Indonesia are other examples where the externally propagated accounting reforms fitted very well into the top political contexts in terms of maintaining legitimacy, but contradicted the public sector accounting traditions, thereby keeping the existing system intact (Khodachek and Timoshenko, 2017; Harun et al., 2012). That public sector accounting reforms have represented facades, simply adding a layer over the existing practices, is also evident in other emerging economies, including Ghana and Benin (Lassou, 2017), Bangladesh (Rajib et al., 2019), Indonesia (Harun et al., 2012), and 
Nepal and Sri Lanka (Adhikari et al., 2013; Yapa and Ukwatte, 2015). In sub-Saharan Africa the adoption of accrual accounting has engendered more harm in practice by opening up a space for corruption, patronage and neopatrimonialism to proliferate (Bakre et al., 2017; Goddard et al., 2016).

Existing work shows that failure, resistance and unintended consequences, including delay and chaos, have become common features of public sector accounting reforms in emerging economies, thereby calling for an in-depth and evidence-based analysis of the implementation phase of reforms in multiple contexts. Van Helden and Uddin (2016) accentuate that multiple and comparative case studies on the diffusion and implementation of public sector accounting reforms in emerging economies are particularly in demand so as to generate insights into the way these reforms are perceived at the implementation stage in different contexts. Presenting the diffusion and implementation of public sector reforms in three emerging economies, Egypt, Nepal and Sri Lanka, we have in this paper responded to this call. These three selected countries are particularly interesting in that they are at different stages in an accrual accounting trajectory. While Nepal has been reverted to the Cash Basis IPSAS, leaving accrual accounting reforms for the future, the latter is the key reform agenda in Sri Lanka, having claimed compliance with the Cash Basis IPSAS (Adhikari et al., 2013). Egypt is apparently in a state of confusion, straddling between cash and accrual accounting reforms, a mixed accounting system being a compromise (Ouda, 2015).

We have approached these multiple and comparative case studies of public sector accounting reforms in three emerging economies drawing on the diffusion of innovations theory (Rogers, 2003; Green et al., 2009; Abrahamson, 1991). The use of diffusion theory is particularly emphasised in public sector accounting research as it enables researchers to move beyond the intuitional analysis of the adoption of reforms, as evident in extant work (Adhikari et al., 2013; Goddard et al., 2016; Harun et al., 2012), and to bring out the salient implementation barriers preventing reforms to engender the intended benefits, a much discussed issue in the public sector accounting context of emerging economies (Van Helden and Uddin, 2016). Few public sector accounting studies in emerging economies (Adhikari et al., 2015), however, draw on diffusion theory, a theoretical gap which this study intends to address.

\section{Diffusion of Innovations Theory}


The diffusion of innovations theory (herein diffusion theory) is perhaps amongst a few theories that have been drawn on by researchers in multiple and diverse disciplines ranging from sociology to education, not least accounting (Green et al., 2009). Earlier understanding of diffusion theory underlies the fact that innovations diffused tend to share similarities and follow similar linear trajectories across a range of contexts (Rogers, 2003). For instance, Abrahamson (1991) has outlined four perspectives, i.e. efficient choice, forced selection, fad and fashion, which triggered the diffusion or rejection of innovations across organisations. The efficient choice perspective is built on the assumption that innovations are diffused only if they can help organisations reduce the performance gaps. The remaining three perspectives assert that similar innovations are diffused to organisations when they face situations of no choice, uncertainty and legitimacy crisis respectively (Malmi, 1991).

Rogers (2003) proposes a linear diffusion trajectory consisting of prior knowledge, persuasion, decision, implementation and conformation. In the context of emerging economies, Adhikari et al. (2015) have drawn on this model to investigate the internal and external circumstances promoting the adoption of the Cash Basis IPSAS in the central government of Nepal. While prior knowledge of the innovations triggers the diffusion process, the likelihood of these innovations to get accepted in a particular context is determined at the persuasion stage (Rogers, 2003). Decisions to accept innovations range from straightforward acceptance to immediate rejection and from later adoption to continued rejection (Ezzamel et al., 2014). Implementation is perhaps the most complex and problematic stage of the diffusion trajectory (Green et al., 2009), as the innovations tend to undergo a process of alteration, modification and reinvention, what Bjornenak (2005, p. 3) has referred to as the 'bundling process', with a view to catering to specific organisational interests and contexts. Such a process offers organisations with the opportunity to achieve conformity without having to put the intended innovations into practice (Hartley and Rashman, 2018; Bekkers and Tummers, 2018). The last stage of the diffusion trajectory is 'confirmation' in which the adopters either embed the innovations or abandon them citing the failure to engender the intended benefits (Rogers, 2003).

In recent studies conducted in the public sector setting, a need for a detailed contextual analysis has been emphasised so as to generate insights into why the diffusion trajectory of innovations adheres to a rather distinct pattern (Vries et al., 2016) and the adoption of certain innovations, for instance accrual accounting, results in unintended consequences in different settings (Ezzamel et al., 2014; Lapsley and Wright, 2004). Jackson and Lapsley (2003) state that the 
implementation stage of public sector innovations, which tends to give rise of unintended consequences, is rather poorly understood as scholars tend to adopt pro-innovation biases. Proinnovation biases imply that the prescribed best practices are always considered by all organsational members, who assume that such practices would bring benefits to their respective organisations (Robertson et al., 1996; Malmi, 1999; Abrahamson, 1991). Issues which are central to the implementation of innovations, including informal networks such as collaboration between organisations, universities and professional institutions, information boundary spanning, networks and communication flows between the key actors at different organisational levels and their engagement in the implementation process, are relatively deemphasised (Vries et al., 2016; Green et al., 2009). In the context of the public sector, professional accounting institutions tend to serve as key agents, having access to up-to-date information on new accounting practices and techniques (Jackson and Lapsley, 2003). They may act as boundary spanners setting up the right channels to facilitate communications with internal and external networks and keeping the members up to date with accounting developments (Swan and Newell, 1995).

Applying diffusion theory, we have in this paper sought to extend prior work in public sector accounting in emerging economies, in particular the work of Adhikari et al. (2015), by illustrating how public sector reforms, i.e. accrual accounting and the Cash Basis IPSAS, have been diffused to Egypt, Nepal and Sri Lanka and analysing the actual level of implementation in practice. We bring out the different individual responses of key actors - public administrators, accountants and professional accountants - in the diffusion process and shed light on various impediments obstructing the implementation of reforms and diffusion trajectories, issues which have remained under-researched in extant public sector accounting work (Jackson and Lapsley, 2003; Ezammel et al., 2014; Christensen and Parker, 2010).

\section{Method}

Despite being different historically and religiously (Adhikari et al., 2013; Ouda, 2015), a similarity of Egypt, Nepal and Sri Lanka underlies their economic development. All these three countries belong to the World Bank's categories of either low-income or lower-middle-income economies, with a significant portion of GDP relying on international aid and loans. For instance, external debts to Nepal, Sri Lanka and Egypt stand at around 30\% (FCGO, 2017), 45\% (Ministry of Finance, 2016) and 33.6\% (World Bank, 2015) of GDP respectively. Such a 
reliance on international resources has put these countries under pressure to adopt internationally prescribed public sector reforms at the institutional (political) level, issues which are already covered in prior work (Adhikari et al., 2013; Adhikari et al., 2015; Ouda, 2015).

These three countries are even more similar when considering their attempts at implementing public sector accounting reforms beginning from the 1980s, predicating improvements in governance and accountability. Sri Lanka is perhaps one of very few cases amongst emerging economies that has been appreciated by the World Bank for the approaches it has taken to implement the Cash Basis IPSAS (World Bank, 2010). Nepal has become a front-runner amongst emerging economies in terms of declaring the adoption of internationally prescribed accounting reforms due to its excessive reliance on international organisations for financial resources and expertise (Adhikari et al., 2015). Egypt is perhaps amongst the few emerging economies in which the conflict between the central government and international organisations in terms of instigating reforms is striking. Through document analysis and semi structured interviews, we have in this paper striven to illustrate the actual level of implementation of public sector accounting reforms in three unique contexts.

Documents we analysed to generate insights into Egyptian public sector accounting reforms include the World Bank's Country Financial Accountability Assessment and reports published by the International Monetary Fund, the European Commission, the United States and the Netherlands. In the case of Nepal, we reviewed the World Bank's reports on public sector accounting and auditing standards, joint reports of the Ministry of Finance and development partners on the portfolio performance review, and the Financial Comptroller General Office's consolidated financial statements. In Sri Lanka, we reviewed the World Bank's reports on financial accountability assessment and international standards, along with the reports issued by the country's two oversight committees, the Committee on Public Enterprise and the Public Accounts Committee.

Twenty semi-structured interviews were conducted in Egypt in 2016. The informants included a Vice Minister of Finance, four senior officers at the Ministry of Finance, seven administrators representing the Central Budgeting Sector and eight Senior Accountants at the Department of End-of-Year Accounts. In Nepal, we undertook twenty-two semi-structured interviews during 2015. Our key interviewees included ten senior and junior accountants at the Financial 
Comptroller General Office, which is a key organ for government accounting in Nepal, six senior government officers at the Ministry of Finance, and six professional accountants at the Accounting Standards Board and the Institute of Chartered Accountants of Nepal. Similarly, twenty semi-structured interviews were conducted in Sri Lanka between 2013 and 2016. Our interviewees in Sri Lanka included four members of the Sri Lanka Public Sector Accounting Standards committee, four government accountants and twelve treasury administrators. The interviews in all three countries lasted between 45 and 90 minutes and were recorded and subsequently transcribed. During the interviews, we raised several concerns with our interviewees, including internal and external circumstances for instigating accounting reforms; the resistance, tensions and challenges in implementing reforms; and the results and outcomes of reforms. We also had three follow-up face-to-face interviews in each country in 2018 to get updated about the recent developments occurring in public sector accounting. Our interviewees included a senior officer, an administrator and a senior accountant in Egypt; a senior accountant, a senior government officer and a professional accountant in Nepal; and a professional accountant, a government accountant and an administrator in Sri Lanka.

At the next stage, we analysed our data by listing the views and issues frequently expressed by our interviewees in each country and identifying themes close to the elements outlined in diffusion theory (Rogers, 2003). We developed two main themes for each country, the first one covering the emergence and dissemination of reforms and the second addressing their implementation. The data representing these two broader themes were then clustered and matched with evidence gathered through our literature review.

\section{Empirical Analysis}

In this section, we discuss the dissemination and implementation of public sector accounting reforms in the central governments of Egypt, Nepal and Sri Lanka respectively (see table 1).

\section{A Mixed System and Fragmentary Approaches to Reforms in Egypt}

\section{Diffusion of a Mixed Accounting System}

Public administration in Egypt has historically been centred on an annual budget. In 2005, following pressures from the World Bank and the International Monetary Fund, the Egyptian Ministry of Finance agreed to make the budget system compatible with the requirements of the 
2001 Government Financial Statistics Manual (GFSM), a manual which is based on accrual principles (IMF, 2001). There was, however, more of a bundling process (Bjornenak, 2005), rather than the replacement of the existing cash practices, which resulted in the emergence of a mixed accounting system, combining elements of both cash and accrual accounting (World Bank, 2015; Ouda, 2015). A senior officer at the Ministry of Finance explained how the mixed system evolved and worked:

The GFSM was layered over the existing cash accounting. The cash basis continued for current expenditures and revenues and the accrual basis was used for capital expenditures and investment. Those assets which last for more than a year, such as office furniture, were required to be considered as capital expenditures and charged on the capital budget.

Unlike the case in many emerging economies, for instance, Nepal (Adhikari et al., 2013), the diffusion of accrual accounting was apparently less susceptible to coercion (through force) in Egypt. In a range of emerging economies, international organisations have employed professional accountants and their associations as a channel through which to communicate the benefits of accrual accounting (Rajib et al., 2019). Such an absence of a professional channel to diffuse the superiority of accrual accounting perhaps serves as a reason why the diffused reforms in Egypt were more focused on improving the existing cash accounting and maintaining consistency with the budget (World Bank, 2015). An expert (qualified) group was formed within the Ministry of Finance, including 'outsiders', i.e. PhD holders from western countries, consultants and expertise from the private sector. The group financed by international organisations worked as informal networks contributing to the Ministry of Finance issuing new Charts of Accounts in 2008. While representing the interests of international organisations, the new charts, which replaced the Government Accounting Act No. 127 of 1981, were a unique innovation in emerging economy contexts requiring public entities to comply with the requirements of both the 2001 Government Financial Statistics Manual and the Cash Basis IPSAS, the following statement of a senior officer at the Ministry of Finance serving as an example:

A general understanding was that the Charts of Accounts would make accounting and budgeting consistent and there would be overall improvements in accounting practices having been supported by the Cash Basis IPSAS. This is a unique way of improving government accounting practices which could meet both the national and international requirements in one go. 
These reform initiatives prompted by the qualified group and the ministry garnered more criticism than support however, when these were communicated to administrators and accountants, thereby stifling the process of implementing reforms.

\section{A Shift Towards the Fragmented Approaches}

Three key barriers have been identified impairing the diffusion trajectory of the Charts of Accounts and the Cash Basis IPSAS at the implementation stage. First, accountants and administrators were unaware of higher remunerations and other additional privileges, for instance, exemption from normal civil service, offered to the members of the qualified group for their role in stimulating reforms. This resulted in the demoralisation of government administrators to engage in the reform process, a senior administrator at the Central Budgeting Sector stated:

We are the implementer of these reforms, but we were never put into a loop. The discrimination between the donor-financed [qualified group] and government-financed staff has given us the impression that we [the government-financed group] are not important staff, and this made us work against the reform process.

The next impediment in implementing these reforms concerned a lack of a boundary spanning process. Instead of elucidating the benefits of reforms in improving accounting practices to accountants and administrators, the focus of the qualified group members was on their instantaneous adoption. Although a few seminars and workshops were facilitated for government accountants and administrators, benefits that these reforms were likely to bring to government entities, as well as the complexities in using cash and accrual simultaneously, were

rarely discussed. A senior accountant from the Department of End-of-Year Accounts commented:

The workshops and seminars were more focused on the importance of maintaining consistency between accounting and budgeting. It was not explained how to link the budgeting structure with the new Chart of Accounts using accounting standards.

Another senior officer at the Ministry of Finance added to this:

This mix of cash and accrual concepts incorporated in the Chart of Accounts has created a great deal of confusion. It is not solely cash accounting, but the provisions for the accounting of fixed assets, liabilities, debtors, creditors and prepayments are not detailed enough. 
The third barrier concerned the dissatisfaction of international organisations about a lack of monitoring of reforms and the attempts to fabricate the results. While officials in Egypt championed the successful implementation of the Charts of Accounts and the Cash Basis IPSAS, information on fixed assets, liabilities, debtors, creditors, prepayments and depreciation charges was absent in the financial statements. The accuracy of the final accounts prepared by the central government was therefore questioned, the World Bank being more critical, referring to reforms as a 'lost opportunity' (World Bank, 2010). The following statement of an officer reflected an emerging tension between the Ministry of Finance and international organisations:

We have made several fragmented and partial reforms to support accounting standards, Charts of Accounts and other parts of public finance. Results are not as expected by practitioners and international organisations if we pick up just one reform, but broader reforms are in effect.

Apparently ongoing public sector accounting reforms in Egypt are more fragmented, prioritising techniques such as the medium-term expenditure framework and the Treasury single account, rather than implementing the Cash Basis IPSAS and accrual accounting.

\section{Pro-Innovation Biases and the Cash Basis IPSAS in Nepal}

\section{Dissemination of the Cash Basis IPSAS}

Accrual accounting was diffused in the public sector of Nepal during the 1980s and 90s, predicating its significance for improving budgetary performance (Adhikari et al., 2013). Normative benefits of accrual accounting were diffused but the inherited complexities were under-estimated. Accrual accounting was eventually replaced by the idea of the Cash Basis IPSAS, the latter appearing to be a means of elevating the quality of accounting information generated and obtaining international recognition. Implicit within the diffusion of the Cash Basis IPSAS was an assertion that the improved accounting information guided by the standard would ultimately result in the adoption of accrual accounting in the longer term having achieved the required accounting infrastructure and capacity (Adhikari et al., 2015). While the professional accounting institutes, such as the Institute of Chartered Accountants of Nepal and the Accounting Standards Board, served as the key channels for communicating the significance of the standard, their efforts were further reinforced by government accountants and administrators, who returned to their work having obtained higher education on public 
sector accounting abroad. An officer at the Ministry of Finance stated: 'Once these officers return to Nepal, they start advocating the importance of the Cash Basis IPSAS'.

Interpersonal networks with government representatives to the Accounting Standards Board and the Institute of Chartered Accountants also contributed to promoting the standard and its subsequent adoption. The requirement to include certain numbers of government officials, mainly from the Ministry of Finance and the Financial Comptroller General Office, has provided these professional accounting bodies with a channel to establish inter personal networks with officials in the ministry and lobby for the reforms. A senior government officer at the Ministry of Finance remarked:

I did not know anything about standards prior to representing the Ministry of Finance at the Accounting Standard Board. Similar to private enterprises, what is wrong if we produce a good quality statement for the government using accounting standards?

The adoption of the Cash Basis IPSAS across public entities was announced in 2009. Being aware of the past failure in executing reforms, international organisations persuaded the implementation of the standard on a trial basis and incrementally across ministries. The standard was referred to as the Nepal Public Sector Accounting Standard so as to ease the implementation process, and two ministries were selected at the outset for a trial. Central to the implementation plan developed by the Ministry of Finance was the adoption of the standard across all central level agencies within the next five years, having evaluated the results of the trial (FCGO, 2017; Ministry of Finance, 2015). Although the dissemination of the standard across ministries has been achieved, the diffusion trajectory has been impaired as the enforcement of the standard in practice has remained far from the reality. Impending Factors of the Cash Basis IPSAS at the Implementation Phase

At the higher (institutional) level the decision to adopt the Cash Basis IPSAS was made through pro-innovation biases (Robertson et al., 2016) and this was starkly apparent. Perceived superiority of the standard had led to other issues in the diffusion trajectory, which could potentially negate its implementation, for instance, communication with the adopters (government accountants and administrators), their engagement in the process and the realisation of technical complexities, becoming de-emphasised. Government accountants involved in day-to-day accounting practice were therefore uncertain as to whether the adoption 
of the standard was an improvement or a setback, an accountant at the Financial Comptroller General Office remarked:

The Cash Basis IPSAS is a setback for us, not an improvement. We already have regulations which allow the reporting of certain accrual items, for instance, outstanding liabilities, creditors and debtors. What an irony higher officers and chartered accountants with no knowledge of our accounting are doing a deal with the World Bank.

The pro-innovation biases at the (higher) institutional level also resulted in limited attention being paid to some of the ambiguous requirements relating to consolidation, third-party payments and the reporting of external assistance laid down in the standard. A senior government accountant commented on such technical ambiguities:

All ministries in which the standard is being piloted are facing similar problems. Neither the Ministry of Finance nor donor agencies provide the accounts of external assistance and donorfunded projects.

Another senior accountant added:

We were told training programmes of professional accounting bodies would focus more on technicalities. However, all we were told during such programmes was the importance of standards. Their [the professional accountants] intention was to use the funding provided by international organisations rather than contribute to our capacity development.

A failure of professional accounting institutions to act as boundary spanners was apparent in the implementation of the standard. This has led to further tensions between these institutions and government accountants, the latter groups being reluctant to involve professional accountants at the implementation phase. A professional accountant commented:

Not a single professional accountant has been recruited by any ministries to facilitate the training programmes. How can standards be implemented excluding professional accountants?

Another professional accountant expressed his scepticism as to whether the implementation of the standard would encounter a similar fate of accrual accounting and wither as time goes by, stating: 
Now that the Cash Basis IPSAS is being revised by the International Federation of Accountants, the Financial Comptroller General Office may easily find an excuse. They can change the plan stating that the country would wait for the revised version of the standard.

The diffusion of the standard has stalled at the implementation phase, although claims have been made that ministries have started preparing their financial statements following the Cash Basis IPSAS (Ministry of Finance, 2015). Such claims seem to be motivated by a desire of achieving international legitimacy, a central issue driving the adoption of reforms in the country since the 1980 s.

\section{Bureaucratic Awareness and Power Struggles in Public Sector Accounting Reforms in Sri Lanka}

Awareness of Public Sector Accounting Reforms

Unlike Egypt and Nepal, the communication flow about public sector reforms amongst the adopters were well articulated in Sri Lanka. The country's well-developed accounting infrastructures and professional institutions established during the colonial period had made public administrators up to date with accounting reforms occurring across countries and act as boundary spanners (Adhikari et al., 2013). Not only international organisations, but also oversight institutions such as the Auditor General Office and the Public Accounts Committee participated in the diffusion of accrual accounting as early as the 1980s, predicating it a stimulus for sound governance and economic growth.

The diffusion of accrual accounting assumed a new importance after the establishment of an independent 'Management Training Unit' in 2001, which was assigned with the task of facilitating training to government accountants and administrators. State institutions such as the Institute of Public Finance and Development of Accountancy also evolved as boundary spanners, organising a series of conferences for public administrators communicating the importance of accrual accounting. A Treasury administrator who attended the conference remarked:

Accrual accounting was a main theme in all these events. We were told how it will help generate reliable information relating to revenues, expenditures, assets and liabilities. 
Implicit in the diffusion trajectory of public sector accounting reforms in Sri Lanka was the capacity building of government accountants and administrators prior to their adoption. Not only were the accountants and administrators offered scholarships to pursue higher education in public sector accounting, several experience sharing tours to New Zealand and Australia were organised enabling them to observe the resulting benefits of accrual accounting. Sri Lanka was therefore far ahead in terms of adopting the Cash Basis IPSAS in the emerging economy context, as its consolidated financial statements based on the standard were issued in 2003. A senior administrator at the Treasury elaborated:

It was a great decision taken by the Treasury to change the format of presenting our consolidated financial statements in accordance with the Cash Basis IPSAS. This has brought us to the attention of international institutions.

Unlike the Cash Basis IPSAS, accrual accounting reforms have taken a rather different trajectory, however, despite agreement on its importance over the last two decades, thereby instigating conflicts and tensions between the key stakeholders and delaying the implementation process.

\section{Complexity and Power Struggle in the Diffusion Trajectory of Accrual Accounting}

Three key issues have been identified during our interviews impending on the diffusion trajectory of accrual accounting at the implementation phase. The first one concerned an underestimation of the complexity of accrual accounting, in particular its requirement for asset valuation and registration. Several efforts made by the State Accounting Department of the Treasury to address the issue of asset registration since 2006 have yielded results far below the expectation. In its first effort, the department streamlined the computer-integrated system of public entities anticipating a simplification in the recording of fixed assets. Next, public entities were allowed to voluntarily adopt the accrual basis Sri Lankan Public Sector Accounting Standards, pronounced by the Institute of Chartered Accountants. A project was also launched aiming to accumulate the assets registration of public entities and prepare a consolidated statement on an accrual basis by 2015. That this project has also yet to have been materialised in practice is evident in the following statement of a professional accountant:

We [Sri Lanka] are presented [by international organisations] as a role model in implementing public sector accounting reforms. However, similar to other countries, we are struggling to cope with accrual requirement; asset valuation is just one example - there are several others. 
Another impending issue on the implementation of accrual accounting appears to be a dispute between professional accountants representing the Institute of Chartered Accountants of Sri Lanka (ICASL) and government accountants. A key cause for the dispute has been the limitation of public sector accounting standards setting committee's membership only to chartered accountants. The institute has also founded a public sector wing with no representation from the Treasury with a view to facilitating trainings on standards for government accountants. These initiatives were perceived as an attempt by professional accountants to exert their domination in the public sector and to seize employment and consultancy opportunities. This triggered resistance, the following statement of a government accountant in the Treasury serving as an example:

The ICASL has increasingly strengthened its grip over the public sector without our consent. Therefore, we have proposed to establish a separate institute for government accountants under the Ministry of Finance.

The third barrier is interesting in that it contradicts the pro-innovation biases as evident in other emerging economies, Nepal serving as an example. Despite the support of international organisations, a lack of political will to implement accrual accounting was clearly evident in Sri Lanka. The public sector accounting context in Sri Lanka in fact resembles those of developed countries in which the politicians have been alleged to undermine accrual accounting by being reluctant to apply accrual information in a day-to-day routine (Wall and Connolly, 2016). Technical ambiguities and the fear of losing control over the budget authority have distanced the politicians from accrual accounting, which is evident in the following statement of a Treasury administrator:

We have drafted and handed over a policy paper on accrual accounting to the Minister of Finance for his consideration. But we cannot say anything at this point as they do not want to give up their control on the budget.

Accrual accounting has therefore entered into a period of uncertainty led to by the absence of a political blessing, a factor which is crucial for the diffusion of any forms of innovation (Rogers, 2003).

\section{Discussion and Conclusion}


Research focusing on the implementation stage of public sector accounting reforms in emerging economies is scarce (Van Helden and Uddin, 2016). The present study adds to prior work delineating the actual level of implementation of reforms in multiple emerging economies, Egypt, Nepal and Sri Lanka. As evident in previous studies (Rogers, 2003; Jackson and Lapsley, 2003; Lapsley and Wright, 2004; Ezzamel et al., 2014; Abrahamson, 1991), the application of diffusion theory has enabled us to bring out the key elements deviating the diffusion trajectory of public sector accounting reforms in Egypt, Nepal and Sri Lanka, particularly at the implementation phase. Such elements include, amongst others, the bundling process, pro-innovation biases, informal and interpersonal networks, a boundary spanning process, organisational communication flows, power disparity and dominance.

Public sector accounting reforms in Egypt feature more of a bundling process and their implementation has been impeded by a failure of a qualified group to act as a boundary spanner, the disparity between the members of the qualified group and ordinary accountants in terms of benefits and privileges, the absence of change agents (e.g. professional accountants) and limited inter-organisational communication flows and networks. Not only are the reforms fragmented, no discernable results have been yielded in terms of improving public governance. Instead, as is the case of many African countries (Bakre et al., 2017; Goddard et al., 2016; Hopper et al., 2017), the adoption of reforms has resulted in instigating bad practices, fabrication of reform results serving as an example. In Nepal, pro-innovation biases, the involvement of the accounting profession and the mobilisation of interpersonal networks have resulted in the adoption of the Cash Basis IPSAS, considering this an initial step towards accrual accounting. However, limited communication flows, including a failure of the professional accounting institutions to perform the role of boundary spanners, underestimation of the complexities of the Cash Basis IPSAS, power struggles between the professional and government accountants, each group attempting to exclude another in the implementation process, have all resulted in making the diffusion trajectory ineffective. Education, training and awareness of government accountants, administrators and auditors have placed Sri Lanka at the next level of public sector accounting reforms, as compared to Egypt and Nepal, enabling the country to implement the Cash Basis IPSAS. However, the implementation of accrual accounting has proved to be far too technical. The reluctance of politicians to abandon their budgetary control and the power struggle between the Treasury and professional accountants to ensure the benefits of reforms and maintain dominance in the public sector, have added to 
further uncertainty in the diffusion trajectory of accrual accounting at the implementation phase.

Diffusion theory has in this way enabled us to bring out some of the under-researched aspects of implementing public sector accounting innovations in emerging economies. Our empirical contribution to extant public sector accounting work in emerging economies is two-fold. First, we have delineated that public sector accounting reforms across emerging economies have not been uniform, presenting practice diversity across countries, ranging from the adoption of the Cash Basis IPSAS to accrual accounting to other fragmented approaches. This practice diversity challenges the global debate of public sector accounting harmonisation articulated by international organisations and standard setters (Argento et al., 2018). Next, extending the findings of prior work in emerging economies (Busca et al., 2016; Goddard et al., 2016; Adhikari et al., 2013 and 2015; Rajib et al., 2019), we have illustrated why the diffusion of public sector accounting reforms and their adoption by emerging economies, as championed by international organisations, has remained ineffective in practice. As such reforms have not only experienced delay and resistance at the implementation stage, as they have been diffused and adopted de-emphasising the specific contextual elements, in many cases they have resulted in internal conflicts and unintended consequences, including the fabrication of results, without any evidence of yielding better results for public sector governance and accountability. We therefore emphasise the need for taking into account the specific context of emerging economies, including the power structure, informal networks and communication flows and the complexity of reforms prior to the diffusion of the best practices.

In all three cases, we have identified that government accountants, the adopters of public sector accounting innovations, are often reluctant to hand over their prerogatives in public sector accounting to professional accountants and other actors. Unless government accountants are allowed to steer public sector accounting reforms, the success of these is therefore uncertain. Instead of delegating the vested power of government accountants to professional accounting institutions and expert groups, the latter can act as boundary spanners communicating the technical complexities of reforms to government accountants, administrators and other stakeholders, including politicians. This may help establish an efficient communication network at different administrative levels and facilitate interpersonal and informal networks, enabling reforms to pass through the diffusion trajectory without being stifled at the implementation phase. We called for further studies of emerging economies, both a single case 
and comparative studies, covering the views and roles of other key actors not covered in this study, for instance, politicians, auditors, consultants and representatives of international organisations. Such studies are paramount so as to broaden our understanding of the diffusion trajectories of public sector accounting reforms and the actual level of implementation.

\section{References}

Abrahamson E (1991) Managing fads and fashions: the diffusion and rejection of innovations. Academcy of Management Review 16(3): 586-612.

Adhikari P, Kuruppu C and Matilal S (2013) Dissemination and institutionalization of public sector accounting reforms in less developed countries: a comparative study of the Nepalese and Sri Lankan central governments. Accounting Forum 37(3): 213-230.

Adhikari P, Kuruppu C, Wynne A and Ambalangodage D (2015) Diffusion of the Cash Basis International Public Sector Accounting Standard (IPSAS) in less developed countries: the case of the Nepali central government. Research in Accounting Emerging Economies 15: 85-108.

Argento D, Peda P and Grossi G (2018) The enabling role of institutional entrepreneurs in the accounting change of a transitional economy. Public Administration \& Development 38(1): $39-49$.

Bakre O, Lauwo S and McCartney S (2017) Western accounting reforms and accountability in wealth redistribution in patronage-based Nigerian society. Accounting, Auditing \& Accountability Journal 30(6): 1288-1308.

Bekkers V and Tummers L (2018) Innovation in the public sector: towards an open and collaborative approach. International Review of Administrative Sciences 84(2): 209-213.

Bjornenak T (1997) Diffusion and accounting: The case of ABC in Norway. Management Accounting Research, 8(2): 3-17.

Brusca I, Gomez-Villegas M and Montesinos V (2016) Public finance management reforms: the role of IPSAS in Latin-America. Public Administration and Development 36(1):51-64.

Christensen M and Parker L (2010) Using ideas to advance professions: public sector accrual accounting. Financial Accountability and Management 26(3): 246-266. 
Vries H, Bekkers V and Tummers L (2016) Innovation in the public sector: a systematic review and future research agenda. Public Administration 94(1): 146-166.

Ezzamel M, Hyndman N, Johnsen, A and Lapsley I (2014) Reforming central government accounting: an evaluation of an accounting innovation. Critical Perspectives on Accounting 25(4/5): 409-422.

Financial Comptroller General Office (FCGO) (2017) Government of Nepal Consolidated Financial Statements (Fiscal Year 2016/16). Kathmandu: GoN.

Green LW, Ottoson JM, Garcia C and Hiatt RA (2009) Diffusion theory and knowledge dissemination, utilization and integration in public health. Annual Review of Public Health, 30: 151-174.

Goddard A, Assad M, Issa S and Malagila, J (2016) The two publics and institutional theory-a study of public sector accounting in Tanzania. Critical Perspectives on Accounting 40 (October): 8-25.

Hartley J and Rashman L (2018) Innovation and inter-organizational learning in the context of public sector reform. International Review of Administrative Sciences 84(2): 231-248.

Harun H, Peursen K and Eggleton I (2012) Institutionalization of accrual accounting in Indonesian public sector. Journal of Accounting \& Organizational Change 8(3): 257-285.

Hopper T (2017) Neopatrimonialism, good governance, corruption and accounting in Africa: idealism vs pragmatism. Journal of Accounting in Emerging Economies 7(2): 225-248.

Hopper T, Lassou P and Soobaroyen T (2017) Globalisation, accounting and developing countries. Critical Perspectives on Accounting 43 (March): 125-148.

International Monetary Fund (IMF) (2001) Government Finance Statistics Manual 2001. Washington: IMF.

International Federation of Accountants (IFAC) (2011) Transition to the Accrual Basis of Accounting: Guidance for Public Sector Entities. New York: IFAC.

IPSASB (2017) International Public Sector Accounting Standard: Financial Reporting Under the Cash Basis of Accounting. New York: IFAC.

Jackson A and Lapsley I (2003) The diffusion of accounting practices in the new managerial public sector. International Journal of Public Sector Management, 16(5): 359-372. 
Lapsley I and Wright E (2004) The diffusion of management accounting innovations in the public sector: a research agenda. Management Accounting Research 15(3): 355-374.

Lassou P (2017) State of government accounting in Ghana and Benin: a "tentative" account". Journal of Accounting in Emerging Economies 7(4): 486-506.

Khodachek I and Timoshenko K (2017) Russian central government budgeting and public sector reform discourses: paradigms, hybrids, and a "third way". International Journal of Public Administration DOI: 10.1080/01900692.2017.1383417.

Malmi T (1999) Activity-based costing diffusion across organisations: an exploratory empirical analysis of Finnish firms. Accounting, Organizations and Society 24(8): 649-672.

Ministry of Finance (MoF) (2015) Nepal Portfolio Performance Review (NPPR). Kathmandu: Government of Nepal.

Ministry of Finance (2016) Annual Report - Sri Lanka. Colombo: Government of Sri Lanka.

Ouda H (2015) Transition requirements of accrual accounting in central government of developed and developing countries: statistical analysis-with special focus on the Netherlands and Egypt. International Journal of Accounting and Finance 4(3): 261-304

Rahaman A and Lawrence S (2001) Public sector accounting and financial management in a developing country organisational context: a three dimensional view. Accounting Forum 25(2): 189-210.

Rajib S, Adhikari P, Hoque M and Akter M (2019) Institutionalisation of the Cash Basis International Public Sector Accounting Standard in the central government of Bangladesh: an example of delay and resistance. Journal of Accounting in Emerging Economies 9(1): 28-50.

Robertson M, Swan J and Newell S (1996) The role of networks in the diffusion of technological innovation. Journal of Management Studies 33(3): 333-359.

Rogers E (2003) Diffusion of Innovations (5th eds). New York: The Free Press.

Swan JA and Newell S (1995) The role of professional associations in technology diffusion. Organisation Studies 16(5): 847-874.

Van Helden J and Uddin S (2016) Public sector management accounting in emerging economies: a literature review. Critical Perspectives on Accounting 41(December): 36-62. 
Wall A and Connolly C (2016) Implementing IFRSs in the UK developed administrations. Accounting, Auditing \& Accountability Journal 29(2): 198-225.

World Bank (2010) Public Financial Management Reform in the Middle East and North Africa: An Overview of Regional Experience, Part II- Individual Country Cases, Report no 55061-MNA. Washington DC: World Bank.

World Bank (2015) Country Partnership Framework for Arab Republic of Egypt (for the Period FY 2015-2019). Egypt Country Management Unit: Middle East and North Africa Region.

Yapa P and Ukwatte S (2015) The New Public Financial Management (NPFM) and Accrual Accounting in Sri Lanka. Research in Accounting in Emerging Economies 15: 7-50. 
Table 1: Public Sector Accounting Reforms in Egypt, Nepal and Sri Lanka Beginning from the 1980s/90s

\begin{tabular}{|c|c|c|c|}
\hline & Egypt & Nepal & Sri Lanka \\
\hline $\begin{array}{l}\text { Reform ideas } \\
\text { diffused }\end{array}$ & $\begin{array}{l}\text { Budgetary reforms during } \\
\text { the 1990s, } \\
\text { Compliance with the } \\
\text { 2001 Government } \\
\text { Financial Statistics } \\
\text { Manual from 2005. }\end{array}$ & $\begin{array}{l}\text { Accrual accounting } \\
\text { during the } 1980 \mathrm{~s} / 90 \mathrm{~s}, \\
\text { The Cash Basis IPSAS } \\
(2007-2018) .\end{array}$ & $\begin{array}{l}\text { Accrual accounting since } \\
\text { the } 1980 \text { s and compliance } \\
\text { with the Cash Basis } \\
\text { IPSAS since } 2003 \text {. }\end{array}$ \\
\hline $\begin{array}{l}\text { Key actors } \\
\text { promoting/pers } \\
\text { uading reforms }\end{array}$ & $\begin{array}{l}\text { The World Bank and the } \\
\text { International Monetary } \\
\text { Fund (mainly for } \\
\text { reinforcing the use of } \\
\text { cash accounting) and the } \\
\text { Ministry of Finance and } \\
\text { an expert (qualified) } \\
\text { group (mainly for } \\
\text { adopting the mixed } \\
\text { accounting and the charts } \\
\text { of accounts). }\end{array}$ & $\begin{array}{l}\text { The Word Bank (both for } \\
\text { accrual accounting and } \\
\text { the Cash Basis IPSAS), } \\
\text { Returning government } \\
\text { accountants and } \\
\text { administrators having } \\
\text { obtained higher education } \\
\text { and government } \\
\text { representatives to } \\
\text { professional institutes (for } \\
\text { the Cash Basis IPSAS). }\end{array}$ & $\begin{array}{l}\text { The Auditor General, the } \\
\text { Public Accounts } \\
\text { Committee, and the } \\
\text { International Monetary } \\
\text { Fund (for accrual } \\
\text { accounting during the } \\
\text { 1980s/90s), } \\
\text { The Treasury, the World } \\
\text { Bank and government } \\
\text { accountants/administrator } \\
\text { s with higher } \\
\text { education/training (for the } \\
\text { Cash Basis IPSAS in } \\
\text { 2003), } \\
\text { The Institute of Charted } \\
\text { Accountants, } \\
\text { International } \\
\text { organisations and the } \\
\text { Treasury (for accrual } \\
\text { accounting since 2006). }\end{array}$ \\
\hline $\begin{array}{l}\text { Decision/imple } \\
\text { mentation/confi } \\
\text { rmation of } \\
\text { reforms }\end{array}$ & $\begin{array}{l}\text { A decision to implement } \\
\text { the chart of accounts } \\
\text { supporting the mixed } \\
\text { method was made in } \\
2008 \text {. }\end{array}$ & $\begin{array}{l}\text { A decision was made to } \\
\text { pilot the Cash Basis } \\
\text { IPSAS in } 2009 .\end{array}$ & $\begin{array}{l}\text { A decision to comply } \\
\text { with the Cash Basis } \\
\text { IPSAS was made in 2003, } \\
\text { The process of assets } \\
\text { registration, as part of } \\
\text { implementing accrual } \\
\text { accounting started in } \\
2006 \text {. }\end{array}$ \\
\hline $\begin{array}{l}\text { Results and } \\
\text { outcomes }\end{array}$ & $\begin{array}{l}\text { Dissatisfactions amongst } \\
\text { the public } \\
\text { administrators/accountant } \\
\text { s due to the involvement }\end{array}$ & $\begin{array}{l}\text { Continuation of the } \\
\text { piloting } \\
\text { of the standard, }\end{array}$ & $\begin{array}{l}\text { A lack of political support } \\
\text { and increasing conflicts } \\
\text { between the public } \\
\text { administrators and }\end{array}$ \\
\hline
\end{tabular}




\begin{tabular}{|l|l|l|l|}
\hline & $\begin{array}{l}\text { of the qualified group and } \\
\text { criticisms by international } \\
\text { organisations have stifled } \\
\text { the reform process, }\end{array}$ & $\begin{array}{l}\text { Delays in the actual } \\
\text { implementation of the } \\
\text { Cash Basis IPSAS due to } \\
\text { internal conflicts and } \\
\text { resistance, as well as the } \\
\text { technical ambiguities } \\
\text { inherited to the standard. }\end{array}$ & $\begin{array}{l}\text { Fragmented approaches } \\
\text { have made accrual } \\
\text { accounting reforms } \\
\text { uncertain. } \\
\text { are being promoted rather } \\
\text { than the Cash Basis } \\
\text { IPSAS and accrual } \\
\text { accounting. }\end{array}$
\end{tabular}

